\title{
Synergism of citrus nematode (Tylenchulus semipenetrans Cobb.) and Colletotrichum gloeosporioides plays a major role in citrus dieback
}

\author{
Muhammad Usman Afzal, Sajid Aleem Khan ${ }^{1, *}$, Nazir. Javid ${ }^{1,}$ and Aman Ullah Malik ${ }^{2}$ \\ ${ }^{1}$ Department of Plant Pathology, University of Agriculture, Faisalabad, Pakistan; ${ }^{2}$ Institute of Horticultural Sciences, \\ University of Agriculture, Faisalabad, Pakistan \\ *Corresponding author’s e-mail: sajid_aleem@uaf.edu.pk
}

\begin{abstract}
Citrus is known as a major fruit due to its high nutritional value and adaptability in tropical and sub-tropical regions. Among diseases, citrus dieback is one of the most threatening diseases in which overall plant growth is reduced. Major causes are Colletotrichum gloeosporioides and citrus nematode (Tylenchulus semipenetrans) with 15-35\% losses all over the world. Plant material was established adopting sanitary measures in earthen pots (12-inch diameter). Fresh culture of $C$. gloeosporioides and $T$. semipenetrans was prepared for the inoculation by following the standard procedures. In the first set, rootstocks were inoculated with $200 \mathrm{~mL}$ of water having spore suspension of $C$. gloeosporioides while in in the second set, inoculation of $T$. semipenetrans was done by using $45 \mathrm{~mL}$ of water suspension having 2000 freshly hatched juveniles per pot, while at the rate of $1 \times 10^{7}$ spores $/ \mathrm{mL}$ per plant. In the third set, the interaction of $C$. gloeosporioides and T. semipenetrans was studied by inoculating selected citrus rootstocks by both pathogens. After four months of inoculation, data were recorded on plant disease index (PDI) along with plant growth parameters (root weight, shoot weight, shoot weight, shoot length and number of leaves). Trifoliate orange and cox mandarin hybrid showed resistance against the development of $T$. semipenetrans while rough lemon, C-35 Citrange and sour orange were found susceptible. There was a significant difference in plant growth parameters between inoculated and healthy plants. Root weight and shoot weight decreased by $8.98 \mathrm{~g}$ and $11.53 \mathrm{~g}$, while root length and shoot length decreased by $7.29 \mathrm{~cm}$ and $13.5 \mathrm{~cm}$ respectively as compared to control treatments in most susceptible rootstocks. Per cent Branch Infection (PBI) and per cent Disease Index (PDI) were maximum $(71.52,37)$ per cent on rough lemon respectively. Results regarding combined inoculation of $C$. gloeosporioides and $T$. semipenetrans showed that there was a significant difference in plant growth parameters between inoculated and healthy plants. In rough lemon, Root weight and shoot weight decreased by 13.86 and $20.57 \mathrm{~g}$ respectively in diseased and healthy plants. Root length and shoot length decreased by 8.37 and $20.04 \mathrm{~cm}$ respectively as compared to control treatments in most susceptible rootstocks. Overall results depicted that inoculation of both pathogens reduced plant growth more severely as compared to their individual application.
\end{abstract}

Keywords: Dieback, citrus, plant growth, synergism, citrus nematode.

\section{INTRODUCTION}

Citrus (Citrus medica) has a great socio-economic and nutritional impact on society in tropical as well as sub-tropical regions (Sidana et al., 2013). In Pakistan, Punjab province supplies high-quality citrus and production-wise Kinnow contributes almost $86 \%$, Musambi covers $10 \%$, Feutral (4\%) and Red Blush (1\%) in citrus production (Imran \& Hajan, 2020). Pakistan has the potential to produce $12-15$ tons per hectare, but the actual yield is much lesser than the potential yield. It is due to multiple factors that are responsible for a big difference between its average and potential yield (Niaz et al., 2004; Mahmood \& Sheikh, 2006; Naseer, 2010). Dieback caused by Colletotrichum gloeosporioides is one of the severe citrus diseases in Pakistan (Rawal and Saxana, 1997; Naqvi, 2000; Alam, 2003; Yesmin et al., 2017). Dieback leads to the sudden death of the plant from top to bottom due to more than one pathogenic factor (Ghosh, 1985). Dieback is a crop limiting factor and emerging as a serious issue of the citrus crop in most countries (Rawal \& Saxana, 1997; Alam, 2003). The drastic percentage of citrus dieback disease on Kagzi lime and Elachi lemon recorded about 100\% and 89.9\%, respectively by Miah and Fakir (1988).

C. gloeosporioides is an airborne disease that causes dieback and wither-tip disease in citrus through toxic metabolites (Sharma and Sharma, 1969; Benyahia et al., 2003; Huang et al., 2013). Citrus nematode has been detected in declined citrus with dieback symptoms like yellowing, wilting,

Afzal, M.U.1, S.A. Khan, N. Javid and A. U. Malik. 2021. Synergism of citrus nematode (Tylenchulus semipenetrans Cobb.) and Colletotrichum gloeosporioides plays a major role in citrus dieback. Pak. J. Agri. Sci. 58:1291-1299.

[Received 24 Mar 2021; Accepted 2 Jul 2021; Published (online) 21 Sep 2021] 
defoliation and death of twigs and branches. A complex of fungi and nematode results in plant wilting. Roots of citrus crop become rotten and dirty and failed to absorb nutrients and water from the soil (Bassanezi et al., 2003; Spina, 2008). Symptoms of twig dieback caused by $C$. gloeosporioides were often observed on citrus trees (Citrus sinensis) advancing slowly. Wilting, yellowing and dropping of leaves occurred. Twigs turned dried having slightly raised, brown to black clumped pustules. (Benyahia et al., 2003; Timmer et al., 2000; Lima et al., 2011).

In Pakistan, citrus nematode (Tylenchulus semipenetrans) has been reported from all the major citrus growing areas with varying degrees of infestations (Iqbal et al., 2006; Mukhtar et al., 2007; Khanzada et al., 2008).

The physiological functions of plant nutrients have been understood well, but there are still unanswered questions regarding the dynamic interaction between nutrients and the plant-pathogen system (Huber, 1996). Citrus nematode attacks the root system of citrus plants and alter the physiology of roots. As the result, nutrient and water supply is reduced due to dysfunctional roots and nutritionally weak citrus plants become susceptible to the attack of other pathogens. C. gloeosporioides is an air-born fungal pathogen and attacks aggressively on the nutritionally weak citrus plant. This synergetic role of $T$. semipenetrans and $C$. gloeosporioides reduces the overall plant growth and increases the magnitude of dieback. The objective of the study was to find out the synergetic effect of Citrus Nematode ( $T$. semipenetrans) and C. gloeosporioides for the development of citrus dieback. There is no work reported addressing the synergism of $T$. semipenetrans and C. gloeosporioides for the citrus dieback development.

\section{MATERIALS AND METHODS}

Establishment of plant material: Disease-free plant material was maintained at Citrus Nursery, University of Agriculture, Faisalabad. Healthy rootstocks (Rough lemon (Citrus jambhiri), C-35 Citrange (Poncirus trifoliate X Citrus sinensis), Cleopatra (Citrus reshni), Sour orange (Citrus X aurantium), Cox mandarin hybrid (Scarlet mandarin $\mathrm{X}$ Trifoliate orange), Carrizo citrange (Citrus $\mathrm{X}$ insitorum) and Trifoliate orange (Poncirus trifoliata), were further tested for fungi and nematode association to ensure disease-free.

All the pot experiments were done by using formalin sterilized sandy loam soil ( $8 \%$ clay, $17 \%$ silt and $72 \%$ sand) in earthen pots ( 12 inches diameter). Care was done to remove the formalin residues before filling pots (Atif et al., 2015). Plants were watered regularly.

Sampling, isolation, purification, identification and preparation of spore suspension of $C$. gloeosporioides: Sampling was done by collecting citrus dieback affected twigs from the Sargodha region $\left(32.0740^{\circ} \mathrm{N}, 72.6861^{\circ} \mathrm{E}\right)$. Isolation of fungal pathogens from collected samples was done by the procedure described by Ricker and Ricker, (1936). Purification and identification of colonized fungi on these pieces were done by the hyphal tip method on Potato dextrose agar (Ellis, 1971). Identification of purified fungal cultures was done on a morphological basis (Barnett and Hunter, 1998).

Pure cultures were further multiplied on PDA plates and incubation was done for seven days. Then produced conidia and mycelia were collected and transferred into a flask having $5 \mathrm{~mL}$ of Triton X-1000 (5\%) and 500mL sterilized water and the flask was shaken vigorously for 10-12 minutes with the help of a mechanical shaker. After shaking, the suspension was passed by a double layer of cheesecloth. The concentration of these spore suspensions was adjusted to $1 \times 10^{7}$ spores $/ \mathrm{mL}$ using Hirschmann hemocytometer (Sivakumar et al., 1997).

Sampling, isolation and identification of T. semipenetrans: Feeder roots along with soil samples were processed for nematode isolation by using different techniques (Baermann funnel method described by McKenry and Roberts, (1985) and Whitehead and Hemming tray method given by Whitehead and Hemming, 1965). Identification was made on morphological features (Inserra et al., 1988). After isolation, T. semipenetrans was multiplied on seven-month-old Citrus jambhiri in pots filled with soil mixture having an equal ratio of sand, silt and clay

Response of different rootstocks against $T$. semipenetrans and C. gloeosporioides: Citrus rootstocks (Rough lemon, C35 Citrange, Cleopatra, Sour orange, Cox mandarin hybrid, Carrizo citrange and Trifoliata orange) were screened against T. semipenetrans, C. gloeosporioides and their combination to assess the effect of these pathogens on plant growth and disease severity.

A screening experiment was conducted in three sets. There were three replications of set and experiment was conducted under CRD. In the first set screening of rootstocks of citrus was done against $C$. gloeosporioides in earthen pots (12 inch diameter) in greenhouse. Established plants of selected rootstocks were inoculated by freshly prepared spore suspension of $C$. gloeosporioides by foliar application with the help of a hand sprayer. The rootstocks were inoculated with $200 \mathrm{ml}$ of water having spore suspension of $C$. gloeosporioides at a rate of $1 \times 10^{7}$ spores $/ \mathrm{mL}$ per plant. There was a control treatment for each rootstock sprayed with distilled water. The pots were irrigated regularly with tap water carefully. After four months of inoculation, data was recorded on disease parameters (total number of branches/plants, infected number of branches /plant, per cent branch infection /plant and plant disease index (PDI) along with plant growth parameters including root weight, shoot weight, root length, shoot length and number of leaves. Per cent disease index (PDI) and percent branch infection /plant were calculated by the given formulas respectively; 
Per cent disease index (\%)

$$
=\frac{\text { Total sum of numerical ratings }}{(\text { No of obs) } \mathrm{x} \text { (Maximum grade in ratting scale })} \times 100
$$

(Abedin and Chowdhury, 1982)

Percent Brach Infection (\%)

$$
=\frac{\text { Total sum of Infected branches }}{\text { Total branches }} \times 100
$$

In the second set, selected rootstocks of citrus were screened out against $T$. semipenetrans under the same planting conditions as used in the first set. There were three replications of second set. Freshly hatched $2^{\text {nd }}$ stage juveniles were counted by using a counting dish. Plants were inoculated with the freshly hatched second-stage juvenile of $T$. semipenetrans by soil application. For this purpose, in the middle of pots, 4-6 holes were made near the plant root system and pointed wood was used to make holes. Inoculation of $T$. semipenetrans was done by using $45 \mathrm{~mL}$ of water suspension having 2000 freshly hatched juveniles per pot. Nematode suspension was poured in each hole equally in all pots and then pots were covered by polythene to avoid drying. Overwatering was avoided to prevent loss of nematodes through leaching. After four months of inoculation, data was recorded on plant growth parameters including root weight, shoot weight, root length, shoot length and number of leaves, while citrus nematode ( $T$. semipenetrans) population $\left(\mathrm{J}_{2} / \mathrm{Root}\right.$ System, $\mathbf{J}_{2} / 100 \mathrm{~mL}$ soil, $\mathrm{J}_{3} /$ Root System, $\mathrm{J}_{4} /$ Root System and adults/Root System) were also recorded.

In third set interaction of $C$. gloeosporioides and $T$. semipenetrans was studied by inoculating selected citrus rootstocks by both pathogens. There were three replications of set three. Inoculation of $C$. gloeosporioides and $T$. semipenetrans was performed similarly as in the first and second sets respectively on the same plants. After four months of inoculation, data was recorded on plant disease index (PDI) along with plant growth parameters (root weight, shoot weight, shoot length and number of leaves.

Statistical analysis: Experiments were conducted using a completely randomized design. All experiments were performed thrice. The collected data were statistically analyzed using Statistix ${ }^{\circledR} 8.1$ software.

\section{RESULTS}

Screening of different citrus rootstocks against $C$. gloeosporioides (percent branch infection and percent disease index): Fig 1. shows that Percent Branch Infection (PBI) was recorded maximum on Rough lemon (71.52) per cent followed by C-35 Citrange, Sour orange and Cleopatra $(65.60,53.21,43.13)$ per cent respectively while minimum on Trifoliata orange (24.45) per cent followed by Carrizo citrange (37.75) per cent and Cox mandarin Hybrid (29.192) per cent. Percent Disease Index (PDI) was recorded maximum on Rough lemon (37) per cent followed by C-35 Citrange, Sour orange and Cleopatra $(21,32,26)$ per cent respectively while minimum on Trifoliata orange (9) per cent followed by Cox mandarin Hybrid (11) per cent and Carrizo citrange (15) per cent.

Screening of different citrus rootstocks against citrus nematode (T. semipenetrans):

Parameters related to citrus nematode ( $T$. semipenetrans) population ( $J_{2} /$ root system, $J_{2} / 100 m L$ soil, $J_{3} /$ root system, $J_{4} /$ root system and adults/root system: A significant difference $(P \leq 0.05)$ in population density of $\mathbf{J}_{2}$ per root system was observed in different rootstocks screened out. Maximum population density of $\mathbf{J}_{2}$ per root system was recorded in Rough lemon (10741) followed by C-35 Citrange, Cleopatra, Sour orange, Cox mandarin hybrid (8916, 6840, $5662,4496)$ respectively, while minimum in Trifoliate orange followed by Carrizo citrange $(981,3177)$ respectively as shown in Fig 2a.

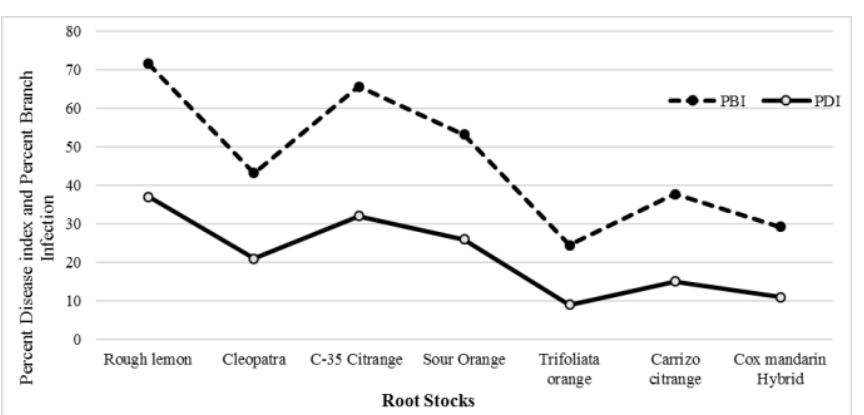

Figure 1. Screening of different citrus rootstocks against Colletotrichum gloeosporioides (Percent Branch Infection and Percent Disease Index)

Count of $\mathrm{J}_{2}$ per $100 \mathrm{~mL}$ soil was observed significantly different $(P \leq 0.05)$ in different rootstocks screened out. Maximum population density of $\mathrm{J}_{2}$ per $100 \mathrm{~mL}$ soil was recorded in Rough lemon (1351) followed by C-35 Citrange, Cleopatra, Sour orange, Cox mandarin hybrid (1068, 826, $654,513)$ respectively, while minimum in Trifoliate orange followed by Carrizo citrange $(107,321)$ respectively as shown in the Fig $2 b$.

A significant difference $(P \leq 0.05)$ in population density of $\mathbf{J}_{3}$ per root system was observed in different rootstocks screened out. Maximum population density of $\mathbf{J}_{3}$ per root system was recorded in Rough lemon (94) followed by C-35 Citrange, Cleopatra, Sour orange, Cox mandarin hybrid $(76,64,48,40)$ respectively, while minimum in Trifoliate orange followed by Carrizo citrange $(9,31)$ respectively as shown in the Fig $2 c$. A significant difference $(P \leq 0.05)$ in population density of $\mathrm{J}_{4}$ per root system was observed in different rootstocks screened out. Maximum population density of $\mathrm{J}_{4}$ per root system was recorded in Rough lemon (467) followed by C-35 Citrange, Cleopatra, Sour orange, Cox mandarin hybrid (387, 318, 266, 219) respectively, while minimum in Trifoliate orange followed by Carrizo citrange $(65,139)$ respectively as shown in the Fig $2 \mathrm{~d}$. 


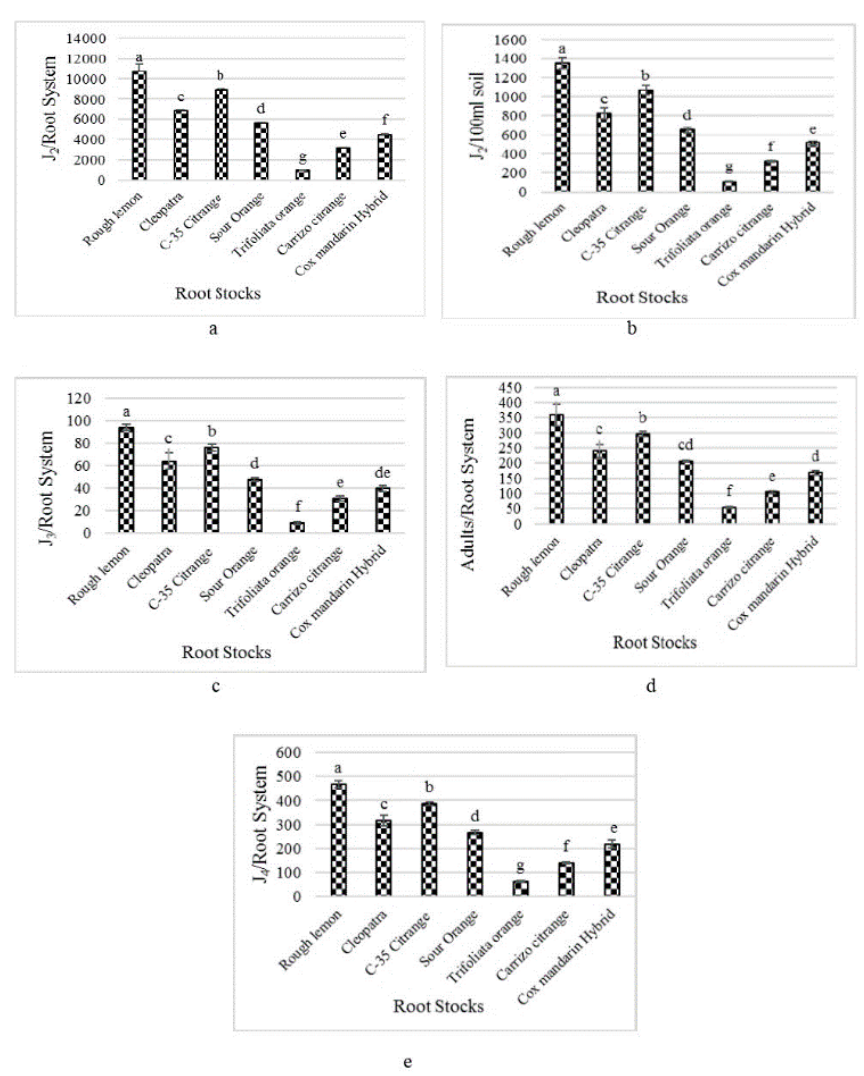

Figure 2. Response of different rootstocks against the development of $T$. semipenetrans (a: $J_{2} / \operatorname{Root}$ System, b: $\mathbf{J}_{2} / 100 \mathrm{~mL}$ soil, c: $\mathrm{J}_{3} / \mathbf{R o o t}$ System, d: J4/Root System, e: Adults/Root System). Means with in a column sharing the same letter are not significantly different from each other at $\mathrm{P}=0.05$ according to Bartlett's test.
Response of different rootstocks shows a significant difference in the development of adults per root system. Maximum population density of $T$. semipenetrans adults per root system was recorded in Rough lemon (358) followed by C-35 Citrange, Cleopatra, Sour orange, Cox mandarin hybrid (296, 240, 206, 168) respectively, while minimum in Trifoliate orange followed by Carrizo citrange $(54,104)$ respectively as shown in the Fig 2e. All the results were significantly different from each other $(P=0.05)$.

Screening of different Citrus rootstocks against $T$. semipenetrans (plant growth parameters): Table 1 shows the reduction in growth parameters of each citrus rootstock compared with its healthy control at $P=0.05$. Root weight was recorded $18.484 \mathrm{~g}$ in rough lemon diseased plants while it was $27.46 \mathrm{~g}$ in healthy rough lemon. Root weight in healthy C-35 Citrange, Sour orange, Cleopatra, Carrizo citrange, cox mandarin hybrid and trifoliate orange was $25.58 \mathrm{~g}, 26.47 \mathrm{~g}$, $23.52 \mathrm{~g}, 26.58 \mathrm{~g}, 29.53 \mathrm{~g}$ and $30.83 \mathrm{~g}$ while was $17.27 \mathrm{~g}, 20.85 \mathrm{~g}$, $17.60 \mathrm{~g}, 21.54 \mathrm{~g}, 25.90 \mathrm{~g}$ and $27.71 \mathrm{~g}$ in diseased plants respectively. Maximum reduction in root weight was observed in rough lemon $(8.98 \mathrm{~g})$ followed by C-35 Citrange, Sour orange, Cleopatra and Carrizo citrange respectively $(8.30 \mathrm{~g}, 5.61 \mathrm{~g}, 5.92 \mathrm{~g}, 5.04 \mathrm{~g})$ while the root weight reduced minimum in trifoliate orange $(3.12 \mathrm{~g})$ followed by cox mandarin hybrid $(3.62 \mathrm{~g})$.

Root length was recorded $37.64 \mathrm{~cm}$ in rough lemon diseased plants while it was $44.93 \mathrm{~cm}$ in healthy rough lemon. Root length in healthy C-35 Citrange, Sour orange, Cleopatra, Carrizo citrange, Cox mandarin hybrid and Trifoliate orange was $40.86 \mathrm{~cm}, 37.08 \mathrm{~cm}, 35.60 \mathrm{~cm}, 39.85 \mathrm{~cm}, 42.67 \mathrm{~cm}$ and $46.68 \mathrm{~cm}$, while was $35.58 \mathrm{~cm}, 32.39 \mathrm{~cm}, 31.06 \mathrm{~cm}, 35.56 \mathrm{~cm}$, $39.82 \mathrm{~cm}$ and $44.16 \mathrm{~cm}$ in diseased plants respectively. Root length was reduced significantly $(P=0.05)$ in rough lemon $(7.19 \mathrm{~cm})$ followed by C-35 Citrange, Sour orange, Cleopatra

Table 1. Screening of different citrus rootstocks against $T$. semipenetrans (plant growth parameters).

\begin{tabular}{|c|c|c|c|c|c|c|}
\hline Rootstock & $\begin{array}{l}\text { Healthy } \\
\text { /Diseased }\end{array}$ & $\begin{array}{c}\text { Root weight } \\
\text { (g) }\end{array}$ & $\begin{array}{l}\text { Root length } \\
\text { (cm) }\end{array}$ & $\begin{array}{l}\text { Shoot weight } \\
\text { (g) }\end{array}$ & $\begin{array}{c}\text { Shoot length } \\
(\mathrm{cm})\end{array}$ & No. of leaves \\
\hline \multirow{2}{*}{ Rough lemon } & Healthy & $27.46 \mathrm{bc}$ & $44.93 \mathrm{ab}$ & $80.81 \mathrm{bcd}$ & $84.48 \mathrm{ab}$ & $123 a$ \\
\hline & Diseased & $18.48 \mathrm{gh}$ & $37.64 \mathrm{ef}$ & $69.28 j$ & $70.98 \mathrm{efg}$ & $102 \mathrm{~g}$ \\
\hline \multirow[t]{2}{*}{ C-35 Citrange } & Healthy & $25.58 \mathrm{~cd}$ & $40.86 \mathrm{~cd}$ & $78.77 \mathrm{def}$ & $80.90 \mathrm{~cd}$ & $112 \mathrm{c}$ \\
\hline & Diseased & $17.27 \mathrm{~h}$ & $35.58 \mathrm{f}$ & 71.50ij & $69.43 \mathrm{fg}$ & $94 \mathrm{~h}$ \\
\hline \multirow[t]{2}{*}{ Sour orange } & Healthy & $26.47 \mathrm{c}$ & $37.08 \mathrm{f}$ & $76.24 \mathrm{fg}$ & $78.04 \mathrm{~d}$ & $108 \mathrm{de}$ \\
\hline & Diseased & $20.85 \mathrm{fg}$ & $32.39 \mathrm{~g}$ & $71.88 \mathrm{ij}$ & $69.16 \mathrm{~g}$ & 93hi \\
\hline \multirow[t]{2}{*}{ Cleopatra } & Healthy & $23.52 \mathrm{de}$ & $35.60 \mathrm{f}$ & $77.21 \mathrm{efg}$ & $79.72 \mathrm{~cd}$ & $103 \mathrm{fg}$ \\
\hline & Diseased & $17.60 \mathrm{~h}$ & $31.06 \mathrm{~g}$ & 72.58hi & $74.08 \mathrm{e}$ & $90 \mathrm{i}$ \\
\hline \multirow[t]{2}{*}{ Carrizo citrange } & Healthy & $26.58 \mathrm{c}$ & 39.85de & 79.72cde & 72.66ef & $116 \mathrm{~b}$ \\
\hline & Diseased & $21.54 \mathrm{ef}$ & $35.56 \mathrm{f}$ & $75.39 \mathrm{gh}$ & $67.82 \mathrm{~g}$ & $106 \mathrm{ef}$ \\
\hline \multirow[t]{2}{*}{ Cox mandarin Hybrid } & Healthy & $29.53 \mathrm{ab}$ & $42.67 \mathrm{bc}$ & 83.40ab & $82.66 \mathrm{bc}$ & $119 b$ \\
\hline & Diseased & $25.90 \mathrm{~cd}$ & $39.82 \mathrm{de}$ & 79.75cde & $79.74 \mathrm{~cd}$ & $111 \mathrm{~cd}$ \\
\hline \multirow[t]{2}{*}{ Trifoliata orange } & Healthy & $30.834 a$ & $46.68 \mathrm{a}$ & $84.93 a$ & $87.32 \mathrm{a}$ & $126 \mathrm{a}$ \\
\hline & Diseased & $27.71 b c$ & $44.16 \mathrm{ab}$ & $82.42 \mathrm{abc}$ & $82.54 b c$ & $123 a$ \\
\hline LSD & - & 2.47 & 2.70 & 3.06 & 3.33 & 3.39 \\
\hline
\end{tabular}

Means within a column sharing the same letter are not significantly different from each other at $P=0.05$ according to Bartlett's test 
and Carrizo citrange respectively $(5.35 \mathrm{~cm}, 4.68 \mathrm{~cm}, 4.54 \mathrm{~cm}$, $4.29 \mathrm{~cm}$ ) and was reduced non-significantly in trifoliate orange and cox mandarin hybrid respectively $(2.85 \mathrm{~cm}$, $2.52 \mathrm{~cm})$.

Shoot weight was recorded $69.28 \mathrm{~g}$ in rough lemon diseased plants while it was $80.81 \mathrm{~g}$ in healthy rough lemon. Shoot weight in healthy C-35 Citrange, Sour orange, Cleopatra, Carrizo citrange, cox mandarin hybrid and trifoliate orange was $78.77,76.24 \mathrm{~g}, 77.21 \mathrm{~g}, 79.72 \mathrm{~g}, 83.40 \mathrm{~g}$ and $84.93 \mathrm{~g}$ while was71.50g, 71.88g, 72.58g, 75.39g, 79.75g and $82.42 \mathrm{~g}$ in diseased plants respectively. Maximum reduction in shoot weight was observed in rough lemon (11.53g) followed by $\mathrm{C}$ 35 Citrange, Sour orange, Cleopatra and Carrizo citrange respectively $(7.27 \mathrm{~g}, 4.36 \mathrm{~g}, 4.63 \mathrm{~g}, 4.33 \mathrm{~g})$ while the shoot weight reduced minimum in trifoliate orange $(2.50 \mathrm{~g})$ followed by cox mandarin hybrid $(3.65 \mathrm{~g})$.

Shoot length was recorded $70.98 \mathrm{~cm}$ in rough lemon diseased plants while it was $84.48 \mathrm{~cm}$ in healthy rough lemon. Shoot length in healthy C-35 Citrange, Sour orange, Cleopatra, Carrizo citrange, cox mandarin hybrid and trifoliate orange was $80.90 \mathrm{~cm}, 78.04 \mathrm{~cm}, 79.72 \mathrm{~cm}, 72.66 \mathrm{~cm}, 82.66 \mathrm{~cm}$ and $87.32 \mathrm{~cm}$ while was $69.43 \mathrm{~cm}, 69.16 \mathrm{~cm}, 74.08 \mathrm{~cm}, 67.82 \mathrm{~cm}$, $79.74 \mathrm{~cm}$ and $82.54 \mathrm{~cm}$ in diseased plants respectively. Shoot length was reduced significantly in rough lemon $(13.5 \mathrm{~cm})$ followed by C-35 Citrange, Sour orange, Cleopatra and Carrizo citrange respectively $(11.46 \mathrm{~cm}, 8.88 \mathrm{~cm}, 5.64 \mathrm{~cm}$ and $4.84 \mathrm{~cm}$ ) and was reduced non-significantly in trifoliate orange and cox mandarin hybrid respectively $(4.78 \mathrm{~cm}$ and $2.92 \mathrm{~cm})$.

The number of leaves per plant were recorded 102 in rough lemon diseased plants while 123 in healthy rough lemon. The number of leaves per plant in healthy C-35 Citrange, Sour orange, Cleopatra, Carrizo citrange, cox mandarin hybrid and trifoliate orange were 112, 108, 103, 116, 119 and 126 while, were 94, 93, 90, 106, 111 and 126 in diseased plants respectively. The number of leaves reduced significantly in rough lemon (21) followed by C-35 Citrange, Sour orange, Cleopatra and Carrizo citrange respectively $(18,15,13,10)$ while reduced non-significantly in trifoliate orange and cox mandarin hybrid respectively $(3,8)$.

Synergistic effect of citrus nematode (T. semipenetrans) + C. gloeosporioides for dieback: Table 2 shows the reduction in growth parameters of each citrus rootstock compared with its healthy control ( $\alpha$ 5\%). Root weight was recorded $14.28 \mathrm{~g}$ in rough lemon diseased plants while it was $28.14 \mathrm{~g}$ in healthy rough lemon. Root weight in healthy C-35 Citrange, Sour orange, Cleopatra, Carrizo citrange, cox mandarin hybrid and trifoliate orange was $24.18 \mathrm{~g}, 26.31 \mathrm{~g}, 24.48 \mathrm{~g}, 27.18 \mathrm{~g}, 31.23 \mathrm{~g}$ and $32.66 \mathrm{~g}$ while was $14.67 \mathrm{~g}, 15.55 \mathrm{~g}, 15.34 \mathrm{~g}, 20.84 \mathrm{~g}, 25.80 \mathrm{~g}$ and $28.56 \mathrm{~g}$ in diseased plants respectively. Maximum reduction in root weight was observed in rough lemon (13.86g) followed by Sour orange, C-35 Citrange and Cleopatra respectively $(10.76 \mathrm{~g}, 9.50 \mathrm{~g}$ and $9.13 \mathrm{~g})$ while the root weight reduced minimum in trifoliate orange $(4.10 \mathrm{~g})$ followed by cox mandarin hybrid and Carrizo citrange $(5.43 \mathrm{~g}$ ) and (6.34) respectively. Root length was recorded $37.44 \mathrm{~cm}$ in rough lemon diseased plants while it was $45.81 \mathrm{~cm}$ in healthy rough lemon. Root length in healthy C-35 Citrange, Sour orange, Cleopatra, Carrizo citrange, cox mandarin hybrid and trifoliate orange was $42.29 \mathrm{~cm}, 35.42 \mathrm{~cm}, 36.15 \mathrm{~cm}, 36.82 \mathrm{~cm}$, $42.81 \mathrm{~cm}$ and $47.26 \mathrm{~cm}$ while was $35.98 \mathrm{~cm}, 28.59 \mathrm{~cm}, 28.46 \mathrm{~cm}$, $32.04 \mathrm{~cm}, 38.80 \mathrm{~cm}$ and $43.70 \mathrm{~cm}$ in diseased plants respectively. Root length was reduced significantly in rough lemon $(8.37 \mathrm{~cm})$ followed by Cleopatra, Sour orange and C35 Citrange respectively $(7.69 \mathrm{~cm}, 6.82 \mathrm{~cm}, 6.31 \mathrm{~cm})$ and was reduced non-significantly in trifoliate orange $(3.56 \mathrm{~cm})$ followed by cox mandarin hybrid and Carrizo citrange respectively $(4.01 \mathrm{~cm}, 4.78 \mathrm{~cm})$.

Table 2. Synergistic effect of citrus nematode (T. semipenetrans) + C. gloeosporioides for dieback.

\begin{tabular}{|c|c|c|c|c|c|c|}
\hline Rootstock & $\begin{array}{l}\text { Healthy } \\
\text { /Diseased }\end{array}$ & $\begin{array}{c}\text { Root weight } \\
\text { (g) }\end{array}$ & $\begin{array}{l}\text { Root length } \\
(\mathrm{cm})\end{array}$ & $\begin{array}{c}\text { Shoot weight } \\
\text { (g) }\end{array}$ & $\begin{array}{c}\text { Shoot length } \\
(\mathrm{cm})\end{array}$ & No. of leaves \\
\hline \multirow[t]{2}{*}{ Rough lemon } & Healthy & $28.14 \mathrm{abc}$ & $45.81 \mathrm{a}$ & $83.65 a b c$ & $83.62 \mathrm{abc}$ & $125 \mathrm{ab}$ \\
\hline & Diseased & $14.28 \mathrm{f}$ & $37.44 \mathrm{cde}$ & $63.08 \mathrm{f}$ & $63.58 \mathrm{de}$ & $95 f g$ \\
\hline \multirow[t]{2}{*}{ C-35 Citrange } & Healthy & $24.18 \mathrm{~cd}$ & $42.29 \mathrm{abc}$ & $79.27 b c$ & $82.50 \mathrm{bc}$ & $115 \mathrm{~cd}$ \\
\hline & Diseased & $14.67 f$ & $35.98 \mathrm{de}$ & $65.30 \mathrm{ef}$ & $67.83 \mathrm{de}$ & $90 \mathrm{gh}$ \\
\hline \multirow[t]{2}{*}{ Sour orange } & Healthy & $26.31 \mathrm{bcd}$ & $35.42 \mathrm{de}$ & $78.22 \mathrm{~cd}$ & $77.56 \mathrm{c}$ & $111 \mathrm{de}$ \\
\hline & Diseased & $15.55 \mathrm{ef}$ & $28.59 f$ & $62.68 f$ & 66.36de & $88 \mathrm{gh}$ \\
\hline \multirow[t]{2}{*}{ Cleopatra } & Healthy & $24.48 \mathrm{~cd}$ & $36.15 \mathrm{de}$ & $78.17 \mathrm{~cd}$ & $78.76 b c$ & 104ef \\
\hline & Diseased & $15.34 \mathrm{ef}$ & $28.46 f$ & $67.58 \mathrm{ef}$ & $68.88 \mathrm{de}$ & $84 \mathrm{~h}$ \\
\hline \multirow[t]{2}{*}{ Carrizo citrange } & Healthy & $27.18 \mathrm{abc}$ & $36.82 \mathrm{de}$ & $77.67 \mathrm{~cd}$ & $70.30 \mathrm{~d}$ & 109de \\
\hline & Diseased & 20.84de & $32.04 \mathrm{ef}$ & 71.15de & $62.66 \mathrm{e}$ & $95 \mathrm{fg}$ \\
\hline \multirow[t]{2}{*}{ Cox mandarin Hybrid } & Healthy & $31.23 \mathrm{ab}$ & $42.81 \mathrm{abc}$ & $85.76 \mathrm{ab}$ & $85.55 \mathrm{ab}$ & $123 b c$ \\
\hline & Diseased & $25.80 \mathrm{bcd}$ & $38.80 \mathrm{bcd}$ & $80.55 \mathrm{abc}$ & $77.78 \mathrm{c}$ & $112 \mathrm{de}$ \\
\hline \multirow[t]{2}{*}{ Trifoliate orange } & Healthy & $32.66 \mathrm{a}$ & $47.26 \mathrm{a}$ & $87.14 \mathrm{a}$ & $89.58 \mathrm{a}$ & $133 a$ \\
\hline & Diseased & $28.56 \mathrm{abc}$ & 43.70ab & $82.47 \mathrm{abc}$ & $82.68 \mathrm{abc}$ & $125 \mathrm{ab}$ \\
\hline HSD & & 5.94 & 5.40 & 7.13 & 7.02 & 9.40 \\
\hline
\end{tabular}

Means within a column sharing the same letter are not significantly different from each other at $P=0.05$ according to Bartlett's test 
Shoot weight was recorded $63.08 \mathrm{~g}$ in rough lemon diseased plants while it was $83.65 \mathrm{~g}$ in healthy rough lemon. Shoot weight in healthy C-35 Citrange, Sour orange, Cleopatra, Carrizo citrange, cox mandarin hybrid and trifoliate orange was $79.27 \mathrm{~g}, 78.22 \mathrm{~g}, 78.17 \mathrm{~g}, 77.67 \mathrm{~g}, 85.76 \mathrm{~g}$ and $87.14 \mathrm{~g}$ while $65.30 \mathrm{~g}, 62.68 \mathrm{~g}, 67.58 \mathrm{~g}, 71.15 \mathrm{~g}, 80.55 \mathrm{~g}$ and $82.47 \mathrm{~g}$ in diseased plants respectively. Maximum reduction in shoot weight was observed in rough lemon $(20.57 \mathrm{~g}$ ) followed by Sour orange, C-35 Citrange and Cleopatra respectively (15.54g, 13.96g, 10.59) while the shoot weight reduced minimum in trifoliate orange $(4.66 \mathrm{~g})$ followed by cox mandarin hybrid and Carrizo citrange respectively $(6.52 \mathrm{~g}, 5.21 \mathrm{~g})$. Shoot length was recorded $63.58 \mathrm{~cm}$ in rough lemon diseased plants while it was $82.62 \mathrm{~cm}$ in healthy rough lemon. Shoot length in healthy C35 Citrange, Sour orange, Cleopatra, Carrizo citrange, cox mandarin hybrid and trifoliate orange was $82.50 \mathrm{~cm}, 77.56 \mathrm{~cm}$, $78.76 \mathrm{~cm}, 70.3 \mathrm{~cm}, 85.55 \mathrm{~cm}$ and $89.58 \mathrm{~cm}$ while $67.83 \mathrm{~cm}$, $66.36 \mathrm{~cm}, 68.88 \mathrm{~cm}, 62.66 \mathrm{~cm}, 77.78 \mathrm{~cm}$ and $82.68 \mathrm{~cm}$ in diseased plants respectively. Shoot length was reduced significantly in rough lemon $(20.04 \mathrm{~cm})$ followed by $\mathrm{C}-35$ Citrange, Sour orange and Cleopatra respectively $(14.67 \mathrm{~cm}$, $11.20 \mathrm{~cm}, 9.88 \mathrm{~cm}$ ) and was reduced non-significantly in trifoliate orange, Carrizo citrange and cox mandarin hybrid respectively $(6.90 \mathrm{~cm}, 7.64 \mathrm{~cm}, 7.77 \mathrm{~cm})$.

The number of leaves per plant were recorded 95 in diseased plants while 125 in healthy rough lemon. The number of leaves per plant in healthy C-35 Citrange, Sour orange, Cleopatra, Carrizo citrange, cox mandarin hybrid and trifoliate orange was 115. 111, 104, 109, 123 and 133 and were 90, 88, 84, 95, 112 and 125 in diseased plants respectively. The number of leaves reduced significantly in rough lemon (30) followed by C-35 Citrange, Sour orange, Cleopatra and Carrizo citrange respectively $(25,23,20,14)$ while reduced non-significantly in trifoliate orange and cox mandarin hybrid respectively $(8,11)$.

\section{DISCUSSION}

Citrus dieback is the emerging threat to the citrus orchards because it does not cause only loss of fruit but the whole plant gradually dies and fruit yield, quality and number of plants per hectare starts to decrease. T. semipenetrans infect the citrus plants and suck the plant food and the efficiency of the plant root system is decreased, as a result, the infected plants become nutrient deficient and became susceptible to the attack of C. gloeosporioides. Therefore, by the involvement of $T$. semipenetrans, the fungal pathogen $C$. gloeosporioides infect the citrus plants more aggressively causing an increased magnitude of dieback.

Cultivation of tolerant or resistant cultivars could be used as an effective tool for the proper and environmentally safe management of diseases, in this way use of pesticides and other laborious management strategies could be eliminated. (Gebhardt and Valkonen, 2001). Plant resistance plays a key role in the management of disease-causing pathogens. In a particular region, it is hard to find such type of cultivars which are resistant to a wide range of pathogens, so it is need of time to discover most threatening and damaging pathogens in a region and find out suitable cultivars having resistance against them. (Pedley and Martin, 2003).

Seven available citrus rootstocks were screened out against the $T$. semipenetrans. All of the root stocks responded differently to the $T$. semipenetrans infestation. Nematode could not establish active feeding sites on the roots of resistant host plants as the result of hypersensitive responses, ultimately female reproduction is reduced. (Williamson and Kumar, 2006). Prasad et al., (1997) claimed Rough lemon and Trifoliate orange as resistant rootstocks against $T$. semipenetrans but the results of the present study contradict this claim in the case of Rough lemon but were in accordance in case of Trifoliate orange. Rootstocks responding differently against $T$. semipenetrans shows that there is one foremost gene or a multiple tandem gene participating in the development of resistance against $T$. semipenetrans. (Ling et al., 2000). Results of the present study were in line with studies of Hutchison, 1985; Verdejo-Lucas et al.2003 and Nazir et al. 2008.

Different crops react similarly to the invasion of different nematodes by changing oxidants and antioxidants. The rate of increase depends upon the host plant, nematode species and initial population. (Davis et al., 2000; Huang et al., 2004; Afifi et al., 2014). The mode by which resistance is inherited is not understood. Further investigations are needed to understand the mechanism of resistance (Kaplan, 1981). Numerous mechanisms including the formation of wound periderm and hypersensitive response are involved in the resistant response. (Van Gundy and Kirpatrick, 1964; Kaplan and O'Bannon, 1981).

In the present investigation, it was also observed that the root system of citrus plants is affected due to semi penetration of T. semipenetrans and continues withdrawal of nutrients results in poor plant growth due to invasion of nematodes and development of feeding sites, the ability of root system to absorb water and nutrient is compromised. Minimum reduction in growth parameters in inoculated treatments as compared to uninoculated treatments was observed in Trifoliata orange and Cox mandarin Hybrid so both of these rootstocks show resistance against $T$. semipenetrans, while Rough lemon and C-35 Citrange show a maximum reduction in growth parameters and show susceptibility to $T$. semipenetrans. Ayazpour et al., (2010) indicated during an investigation that inoculation of T. semipenetrans to the citrus plants results in decreased plant growth, plants facing nematode invasion show decreased root weight and shoot weight. Results of the present study were in conformity with Deka et al. (2003) and Montasser et al. (2012).

Citrus plants are often facing biotic and abiotic stresses screening is a high priority goal for the selection of resistant 
germplasm. This is of much importance for the citrus rootstocks which are severely damaged by the fungal pathogens. All the seven citrus rootstocks were screened out against $C$. gloeosporioides to assess the level of infection in terms of per cent disease index (PDI) and per cent branch infection (PBI). Results indicated that Trifoliata orange and Carrizo citrange showed resistance against infection of $C$. gloeosporioides while Rough lemon, C-35 Citrange and Sour orange show maximum infection exhibiting susceptibility. Screening of citrus rootstocks against $C$. gloeosporioides is not reported from previous literature. Although pathogenicity of $C$. gloeosporioides has been confirmed by Benyahia et al. 2003; Ajay 2014; Ramos et al. 2016 and Mayorquin et al. 2019.

Pathogen attack to healthy plant results in impaired physiology reduced nutrient uptake with less assimilation and translocation from the root system to the shoot system. (Marschner, 1995). Invading pathogens consume a significant amount of nutrients for self-establishment which results in a reduced availability of nutrients for the host plant and host susceptibility is increased due to nutrient deficiency (Timonin, 1965). In the present study, a screening experiment was conducted in which selected rootstocks of citrus were screened out against citrus nematode ( $T$. semipenetrans) and C. gloeosporioides together. Results of revealed that when the plants were exposed to both pathogens at the same time, plant growth is affected with a greater magnitude as of plants exposed to $T$. semipenetrans and $C$. gloeosporioides individually. Trifoliata orange and Cox mandarin hybrid performed best and exhibit a minimum reduction in plant growth parameters in inoculated or diseased plants as compare to healthy plants. Rough lemon, C-35 Citrange and Sour orange indicated maximum susceptibility and show a maximum reduction in plant growth parameters in inoculated or diseased plants as compared to healthy plants. Both of the pathogens infecting citrus plants at the same time might have a synergetic relationship resulting in increased damage to the citrus plants. When the root system of citrus plants is invaded by the $T$. semipenetrans, a sufficient supply of water and nutrients is disturbed, so the nutrient-deficient plants might be more susceptible due to physiological changes and could not resist the fungal infection. Safdar et al. (2013) conducted an experiment in which both Fusarium semitectum, and $T$. semipenetrans were inoculated together and cause more plant growth reduction as compared to their individual application. During interaction, the nematode plays the primary role as a modifier of the host, making it more susceptible to other pathogens (Pitcher, 1978; Powell, 1979). Results of the present study confirmed the findings of different workers who worked on the synergism of fungi and plant-parasitic nematodes (Nicholson et al., 1985; Melgar et al., 1994; Yang and Rizvi, 1994; Roy et al., 1997; Gao et al., 2006).
Conclusion: The herein reported studies were conducted to explore the synergetic role of $T$. semipenetrans and $C$. gloeosporioides for the development of citrus dieback. Different available citrus root stocks were tested against both pathogens individually and in combination. Results indicated that when both pathogens attack simultaneously, there is higher magnitude of dieback as compare to their individual attack.

Acknowledgement: Financial support for this research work was provided by Higher education commission of Pakistan.

\section{REFERENCES}

Abedin, M.Z. and M.K. Chowdhury. 1982. Procedures of data collection in major field crops. Bangla. Agric. Res. inst. Pp.14.

Afifi, A., A. Al-Sayed, N. Mahfoud and A. Farahat. 2014. Enzymatic and non-enzymatic oxidants and antioxidants involved in defense mechanisms against root-knot, reniform and citrus nematodes in their hosts. Egypt. J. Agronema. 13:172-188.

Ajay Kumar, G. 2014. Colletotrichum gloeosporioides: biology, pathogenicity and management in India. J. Plant. Physiol. Pathol. 2:2-11.

Alam, S. M. K. 2003. Survey of citrus diseases. Plant Pathology Research. Annual Report. Plant Pathology Division, BARI. pp.33-37.

Atif, H.M., N. Javed, S.A. Khan, S. Ahmed and M. Raheel. 2015. Virulence of entomopathogenic nematodes against Meloidogyne incognita (Kofoid and White, 1919) Chitwood (1949) for invasion, development and reproduction at different application times in brinjal roots. Int. J. Agric. Biol. 1560-8530.

Ayazpour, K., H. Hasanzadeh and M.S. Arabzadegan. 2010. Evaluation of the control of citrus nematode (Tylenchulus semipenetrans) by leaf extracts of many plants and their effects on plant growth. Afr. J. Agric. Res. 5:1876-1880.

Barnett, H.L. and B.B. Hunter. 1998. Illustrated genera of imperfect fungi. 4th ed. APS Press. ISBN 978-0-89054192-0.

Bassanezi, R. B., A.B. Filho, L. Amorim, N.G. Fernandes, T.R. Gottwald and J.M. Bove. 2003. Spatial and temporal analyses of citrus sudden death as a tool to generate hypotheses concerning its etiology. Phyto. Pathol. 93:502-512.

Benyahia, H., A., Jrifi, C., Smaili, M., Afellah, L.W., Timmer. 2003. First report of Colletotrichum gloeosporioides causing withrtip on twigs and tear stain on fruit of citrus in Morocco. Plant. Pathol.52:798-798.

Cheema, I. A and Hajan K. J. Growth of Citrus Fruits in Pakistan. Amaz. Invest. 935:74-81. 
Davis, E.L., R.S. Hussey, T.J. Baum, J. Barker, A. Schots, M.N. Rosso and P. Abad. 2000. Nematode parasitism genes. Annu. Rev. Phytopathol. 38:356-396.

Deka, R., A. K. Sinha and P. P. Neog. 2003. Pathogenicity of the citrus nematode, Tylenchulus semipenetrans on Citrus jambhiri. Indian J. Nematol. 33:63-64.

Duncan, L. W. and E. Cohn. 1990. Nematode parasites of citrus. Plant-parasitic nematodes in subtropical and tropical agriculture. Wallingford, UK: CAB International. pp. 321-346

Ellis, M.B. 1971. More Dematiaceous Hypomycetes. CMI, Kew, Surrey, England. Pp. 507.

Gao, X., T.A. Jackson, G.L. Hartman and T.L. Niblack. 2006. Interaction between soybean cyst nematode and Fusarium solani f. sp. glycines, based on greenhouse factorial experiments. Phytopathology. 96:1409-1415.

Gebhardt, C. and J.P.T. Valkonen. 2001. Organization of genes controlling disease resistance in the potato genome. Annu. Rev. Phytopathol. 39:79-102.

Ghosh, S.P. 1985. Horticulture in Northeast India. New Delhi: Associate Publishing Company.

Huang, F., G.Q. Chen, X. Hou, Y.S. Fu, L. Cai, K. D. Hyde and H.Y. Li. 2013. Colletotrichum species associated with cultivated citrus in China. Fungal. Divers. 61:61-74.

Huang, G., R. Dong, T. Maier, R. Allen, E.L. Davis, T.J. Baum and R.S. Hussey. 2004. Use of solid-phase sub active hybridization for the identification of parasitism gene candidates from the root-knot nematode, Meloidogyne incognita. Mol. Plant. Pathol. 5:217-222.

Huber, M.D. 1996. Introduction in Engelhard W.A. (Ed.), Management of Diseases with Macro and Microelements, APS Press, Minneapolis, USA.pp.217.

Hutchison, D. J. 1985. Rootstock development, screening and selection for disease tolerance and horticultural characteristics. Fruit Var. J. 39:21-25.

Inserra, R.N., R.P. Esser, and J.H. O'Bannon. 1988. Identification of Tylenchulus species from Florida. Nematology Circular 153, Florida Department of Agriculture \& Consumer Services, Division of Plant Industry. pp.1-4.

Iqbal, M.A., T. Mukhtar, R. Ahmad and H. U. Khan. 2006. Ecological prevalence of Tylenchulus semipenetrans in four districts of the Punjab province, Pakistan. Pak. J. Nematol. 24:19-26.

Kaplan D.T. 1981. Characterization of citrus rootstock responses to Tylenchulus semipenetrans (Cobb). J. Nematol. 13:492-498.

Kaplan, D.T. and J. H. O'Bannon. 1981. Evaluation and nature of citrus nematode resistance in 'Swingle' citrumelo. (Tylenchulus semipenetrans, Florida). Proc. Fla. State. Hort. Soc. 94:33-36.

Khanzada, S.A., A. Iqbal, A. Munir, K. Burney, S. Hameed and H.U. Rehman. 2008. Incidence and distribution of citrus nematode Tylenchulus semipenetrans in citrus orchards of Punjab. Pak. J. Nematol. 26:51-58.

Lima, W.G., M.B. Spósito, L. Amorim, F.P. Golcalves, P.A.M. de Filho. 2011. Colletotrichum gloeosporioides, a new causal agent of citrus post-bloom fruit drop. Eur. J. Plant. Pathol. 13:157-165.

Ling, P., L.W. Duncan, Z. Deng, D. Dunn, X. Hu, S. Huang, and F. G. Gmitter Jr. 2000. Inheritance of citrus nematode resistance and its linkage with molecular markers. Theor. Appl. Genet. 100:1010-1017.

Mahmood, M.A. and A.D. Sheikh. 2006. Citrus export system in Pakistan. J. Agric. Res. 44:229-238.

Marschner, H. 1995. Mineral Nutrition of Higher Plants, 2nd ed., Academic Press, London. 889.

Mayorquin, J.S., M.T. Nouri, B.B. Peacock, F.P. Trouillas, G.W. Douhan, C. Kallsen and A. Eskalen. 2019. Identification, Pathogenicity, and Spore Trapping of Colletotrichum karstii Associated with Twig and Shoot Dieback in California. Plant. Dis. 103:1464-1473.

McKenry, M.V. and Roberts, P.A. 1985. Phyto nematology study guide. Publications, Division of Agriculture and Natural Resources, University of California.

Melgar, J., K.W. Roy and T.S. Abney. 1994. Sudden death syndrome of soybean: Etiology, symptomatology, and effects of irrigation and Heterodera glycines on incidence and severity under field conditions. Can. J. Bot.72:1647-1653.

Miah, A.J. and G.A. Fakir. 1988. Investigation into tlle cause of dieback of Cirrus spp. In Bangladesh. Bang. J. Plant Pathol. 4:103-110.

Montasser, S.A., A.E. Abd El-Wahab, M.M.M. AbdElgawad, H. Abd-El-Khair, F.H.K. Faika and M.M.A. Hammam. 2012. Effects of some fungi and bacteria as bio-control agents against citrus nematode Tylenchulus semipenetrans Cobb. Res. J. Appl. Sci. 8:5436-5444.

Mukhtar, T., R. Ahmad, M.Z. Kayani and G. Irshad. 2007. Occurrence of citrus nematode (Tylenchulus semipenetrans) in Sargodha district. Pak. J. Phytopathol. 19:40-43.

Naqvi, S.A.M.H. 2000. Managing Phytophthora diseases on citrus. Indian J. Hortic. 44:5-9.

Naseer, M. 2010. Export of Kinnow. Report by trade development authority of Pakistan government of Pakistan, Faisalabad.

Nazir, J., M. Javed, M. Khan and M. Inam-Ul-Haq. 2008. Reaction of various citrus root stocks (germplasm) against citrus root nematode (Tylenchulus semipenetrans Cobb.). Pak. J. Bot. 40:2693-2696.

Niaz, A.C., M.N. Maken and S.A. Malik. 2004. Native home, historical background and importance of citrus fruits in Pakistan. In: Proc. $1_{\text {st }}$ Int. Conf. Citriculture. Uni. Agric. Faisalabad. 28-29 48-56.

Nicholson, R.L., G.B. Bergeson, F.P. De Gennaro and D.M. Viveiros. 1985. Single and combined effects of the lesion 
nematode and Colletotrichum graminicola on growth and anthracnose leaf blight of corn. Phytopath. 75:654-661.

Pedley, K.F. and G.B. Martin. 2003. Molecular basis of Ptomediated resistance to bacterial speck disease in tomato. Annu. Rev. Phytopathol.41: 215-243.

Pitcher, R.S. 1978. Interactions of nematodes with other pathogens. In: Plant nematology (ed. J.F. Southey). Her Majesty's Stationery Office, Ministry of Agriculture, Fisheries and Food, London, UK, pp. 63-77.

Powell, N.T. 1979. Internal synergism among organisms inducing disease. In Plant disease. An. Adv. Treatis. 4:113-133.

Prasad, M.B.N.V., R. Singh, A. Rekha and R. Chand. 1997. Evaluation of lemon cultivars and acid lime $\mathrm{x}$ lemon hybrids for resistance to Xanthomonas axonopodis pv. citri. Scientia. Hort. 71:367-272.

Ramos, A.P., P. Talhinhas, S. Sreenivasaprasad, H. Oliveira. 2016. Characterization of Colletotrichum gloeosporioides, as the main causal agent of citrus anthracnose, and C. karstii as species preferentially associated with lemon twig dieback in Portugal. Phytoparasitica 44:549-561.

Rawal, R.D. and A.K. Saxsana. 1997. Diseases of dryland horticulture and their management. In Silver Jubilee National Symposium Arid Horticulture, HISAR Proceedings, HSH/CCS, Hisar, HAU. pp.5-7

Ricker A.H. and R.B. Ricker. 1936. Introduction of Research on Plant Diseases. John Swift Co, New York, USA.

Roy, K.W. 1997. Fusarium solani on soybean roots: Nomenclature of causal agent of the sudden death syndrome and identity and relevance of $F$. solani form B. Pl. Dis. 81:259-266.

Safdar, A., N. Javed, S.A. Khan, H. Safdar, I.U. Haq, H. Abbas and Z. Ullah. 2013. Synergistic effect of a fungus, Fusarium semitectum, and a nematode, Tylenchulus semipenetrans, on citrus decline. Pak. J. Zool. 45:643651.

Sharma, M.C. and B.C. Sharma. 1969. Toxic metabolite production by Colletotrichum gloeosporioides causing citrus dieback in India. Ind. phytopathol.22:65-73.
Sidana, J., V. Saini, S. Dahiya, P. Nain and S. Bala. 2013. A Review on Citrus "The Boon of Nature". Int. J. Pharm. Sci. Rev. Res. 18:20-27.

Sivakumar, D., R.S.W. Wijeratnam, R.L.C. Wijesundera and M. Abeysekera. 1997. Postharvest Diseases of Rambutan (Nephelium lappaceum) in the Western Province. J. Nat. Sci. Council. Sri Lanka. 25:225-229.

Spina, S., V. Coco, A. Gentile, A. Cataraand and G. Cirvilleri. 2008. Association of Fusariumsolani with rol ABC and wild type Troyer Citrange. J. Pl. Pathol. 90:479-486.

Timmer, L.W., S.M. Garnsey, J.H. Graham. 2000. Compendium of Citrus Diseases, 2nd edition. The American Phytopathological Society, USA.

Timonin, M.E. 1965. Interaction of higher plants and soil microorganisms. In Microbiology and soil fertility, in Gilmore C.M., Allen O.N.(Eds.), Corvallis, OR, Oregon State University Press.135-138.

Van Gundy S.D. and J.D. Kirkpatrick. 1964. Nature of resistance in certain citrus rootstocks to citrus nematode. Phytopath. 54:419-427.

Verdejo-Lucas, S., M. Galeano, F.J. Sorribas, J.B. Forner and A. Alcaide. 2003. Effect on resistance to Tylenchulus semipenetrans of hybrid citrus rootstocks subjected to continuous exposure to high population densities of the nematode. Eur. J. Plant. Pathol. 109:427-433.

Whitehead, A.G. and A.K. Hemming. 1965. Comparison of quantitative method of extracting the small vermiform nematode from soil. Ann. Appl. Biol. 55:25-38.

Williamson, V.M. and A. Kumar. 2006. Nematode resistance in plants: the battle underground. Trends. Genet. 22:396403.

Yang, X.B. and S.S.A. Rizvi. 1994. First report of sudden death syndrome of soybean in Iowa. Pl. Dis. 78:830.

Yesmin, K., M. Ahmad, M.B. Momtaz and K. Begum. 2017. Effect of fungicides and plant extracts in the management of foliar, twig and fruit diseases of citrus (Citrus limon). J. Environ. Sci. Natur. Res. 10:93-100. 